\title{
Five new taxa of Nepenthes (Nepenthaceae) from North and West Sumatra.
}

\author{
Joachim Nerz, Arndstr. 2, 71032 Böblingen, Germany \\ Andreas Wistuba, Mudauer Ring 227, 68259 Mannheim, Germany
}

During three field trips in 1986, 1989 and 1992 we examined several locations of Nepenthaceae in West and North Sumatra. We further studied herbarium specimens at the herbaria of Leiden (The Netherlands) and Bogor (Indonesia).

From these studies we concluded to describe five new taxa of Nepenthaceae including four new species. From the Lake Toba region in North Sumatra we describe a new species, which is closely related to Nepenthes carunculata, but differs in some morphological features that justify the establishment of a new taxon. Two new species related to Nepenthes dubia and Nepenthes inermis, and one, which is related to Nepenthes rafflesiana and Nepenthes sumatrana, all from West Sumatra are described. From our studies on Nepenthes carunculata at different locations we further decided to describe a new variety.

Nepenthes talangensis Nerz et Wistuba spec. nov.

Folia mediocria, sessilia, lamina spathulato-lanceolata, nervis longitudionalibus utrinque 3-5, basi cordata semiamplexicauli, vagina 0 . Ascidia rosularum magnitudine mediocria infundibuliformia, alis 2 fimbriatis; peristomio operculum versus acuminato, in collum breve elevato, 8-15 mm lato, costis 1/3-1 mm distantibus, dentibus 1 x longioribus quam latis; operculo ovato, facie inferiore plano. Ascidia su periora magnitu dine mediocria, infundibuliformia costis 2; peristomio operculum versus acuminato, in collum breve elevato, 8-15 mm lato, costis $1 / 3-1 \mathrm{~mm}$ distantibus; dentibus $2-3 \times$ longioribus quam latis. Operculo ovato facie inferiore plano. Inflorescentia racemus parvus, pedicellis $8-9 \mathrm{~mm}$ longis omnibus 1-floris. Indumentum in partibus vegetativis parcum, margo laminae pubescens.

Holo-Typus: Nerz 2501, short vine with flower and pitcher, G. Talang, $2200 \mathrm{~m}$, W-Sumatra, 06.09.1986 (L).

Plants usually growing as rosettes and only rarely climbing. Climbing stems reaching up to $2-3 \mathrm{~m}$ high, the part with adult leaves $6-10 \mathrm{~mm}$ thick, cylindrical to obtusely angular, internodes $0.5-10 \mathrm{~cm}$ long, leaves of the rosettes and climbing stems thick, coriaceous sessile, lanceolate-spathulate, about $10-15 \mathrm{~cm}$ long, up to $3 \mathrm{~cm}$ broad, apically acute or obtuse, attenuate towards the base, leaves clasping the stem, not decurrent; Pennate nerves, irregularly reticulate, on each side several (10-15) originating irregularly from the midrib, longitudinal nerves running parallel in the outer $1 / 3$ part of the lamina. Tendrils usually without curl, once to twice as long as the lamina. Pitchers of the rossettes originating with a short curve, $5 \mathrm{~mm}$ wide from the hanging end of the tendril, thick-coriaceous, widely infundibuliform, $8-12 \mathrm{~cm}$ high, 3$5 \mathrm{~cm}$ wide, somewhat contracted below the mouth, with 2 fringed wings. The wings $2-$ $5 \mathrm{~mm}$ wide, the fringe segments $3-10 \mathrm{~mm}$ long, 0,5-1,0 $\mathrm{mm}$ apart; mouth almost horizontal in front, elevated towards the lid and elongated into a short neck. Peristome flattened, 8-15 mm wide, the ribs $1 / 3-1 \mathrm{~mm}$ apart, the teeth of the inner margin 2-3 times as long as broad. Innerside of the pitcher wholly glandular with a glandless triangle below the lid. Large slightly overarched glands, $300 / \mathrm{cm}^{2}$ in the lower part of the pitcher, smaller ones, $500 / \mathrm{cm}^{2}$ in the upper part. Lid broadly ovate, undulate at the margin. Lower surface without appendage, with rather large glands, especially near 


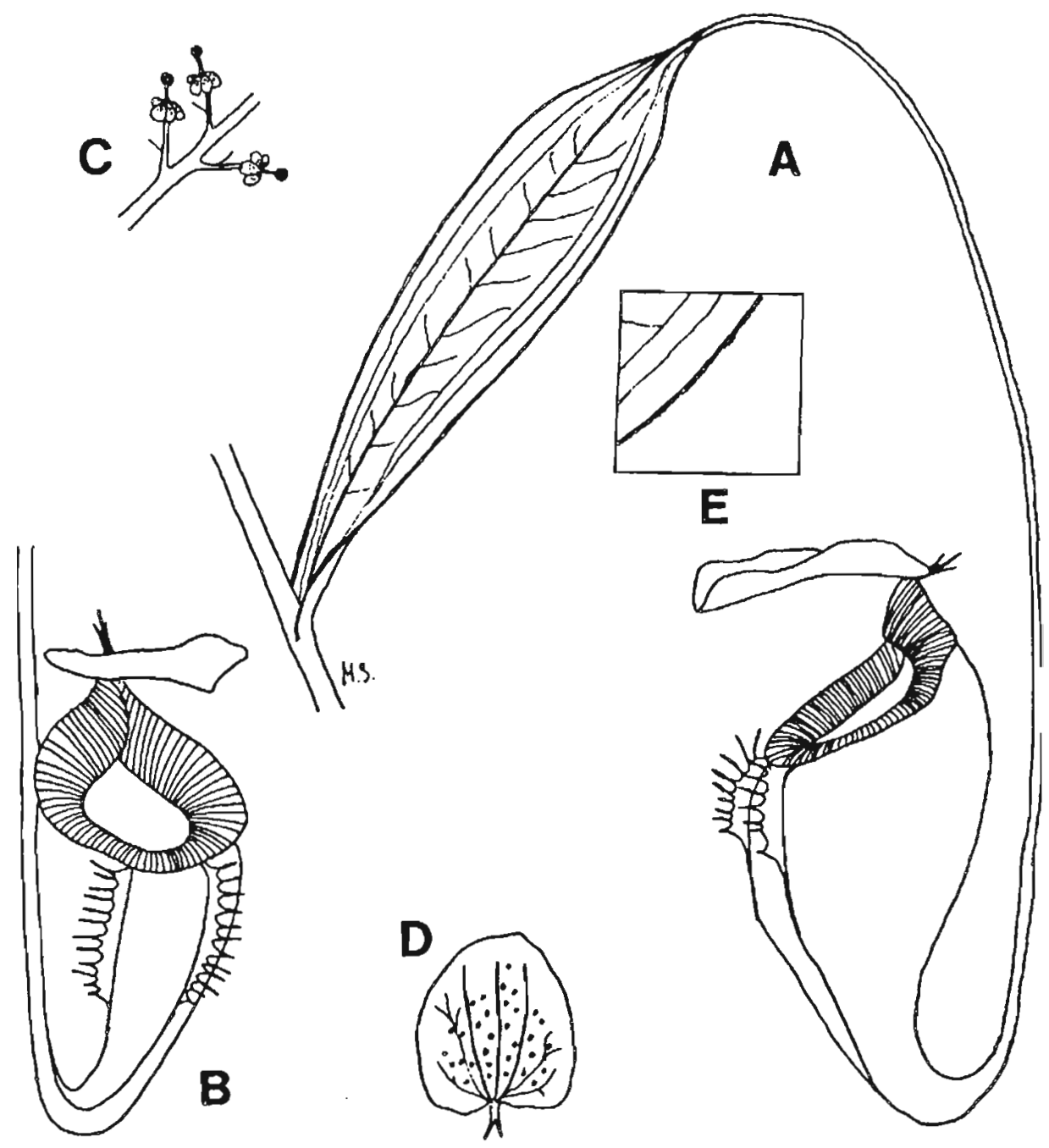

Fig. 1 Nepenthes talangensis (Nerz et Wistuba) A. leaf and pitcher of climbing stem (x 318); B. ground pitcher (x 1/2); C. part of male inflorescense (x 3/4); D. lid (x 0,5); E. part of leaf (x 1).

the midrib, glandless near the margin. Three prominent nerves on each side of the midrib. Spur broad and flattened, 2-5 mm long, branched, inserted close to the lid. Pitchers of the climbing stems originating with a short curve, $5 \mathrm{~mm}$ wide from the hanging end of the tendril, thick-coriaceous, tubulous to narrow infundibuliform in the lower half, ovate in the upper half, $8-12 \mathrm{~cm}$ high, $3-5 \mathrm{~cm}$ wide, somewhat contracted below the mouth, with 2 prominent ribs; mouth almost horizontal in front, elevated towards the lid and elongated into a short neck. Peristome flattened, $8-15 \mathrm{~mm}$ wide, the ribs 1/3-1 $\mathrm{mm}$ apart, the teeth of the inner margin 2-3 times as long as broad. Interior surface of the pitcher wholly glandular with a glandless triangle blow the lid. Large, slightly overarched glands, $300 / \mathrm{cm}^{2}$ in the lower part of the pitcher, smaller ones, $500 /$ $\mathrm{cm}^{2}$ in the upper part. Lid broadly ovate, undulate at the margin. Lower surface 
without appendage, with rather large glands, especially near the midrib, glandless near the margin. Three prominent nerves on each side of the midrib. Spur broad and flattened, 2-5 mm long, branched, inserted close to the lid. Male inflorescence a raceme, the peduncle $4-5 \mathrm{~mm}$ long, $1-1,5 \mathrm{~mm}$ thick, the axis $6-8 \mathrm{~cm}$ long, obtusely angular, the pedicels all of them 1 flowered, the lower ones $10 \mathrm{~mm}$ long, the upper ones a little shorter, almost all of them with a filiform bract, up to $4 \mathrm{~mm}$ long. Tepals elliptical to oblong, $4 \mathrm{~mm}$ long. Staminal column, the anthers included, 3-4 mm long. Female inflorescence unknown. Indumentum on the vegetative part very sparse with non branched hairs, margin of the leaves, densely covered with non branched hairs. Indumentum of inflorescence very sparse. Colour of herbarium specimens: Brown to dark-brown. Colour of living specimens: Vegetative parts light green, leaves with white hair at the margins, pitchers yellowish-white with numerous dark red spots. Peristome yellow or red, lid yellowish white with numerous red spots.

\section{Distribution and ecology:}

West Sumatra, Gunung Talang, $2200 \mathrm{~m}-2600 \mathrm{~m}$ altitude.

In alpine regions above the tree-zone, usually growing as rosettes and short shoots at the ground, sometimes climbing between scrubs like Rhododendron. Nepenthaceae growing on the same mountain are Nepenthes inermis, $N$. carunculata and $N$. gymnamphora, which all grow in different habitats at lower altitudes. Hybrids with $N$. inermis were observed.

\section{Notes:}

Danser, according to data given in his monograph of 1928, examined material of this species (Bünnemeijer 2552 (L); Bünnemeijer 5398 (L); Bünnemeijer 6740 (BO)). Erroneously he placed these specimens under Nepenthes bongso. Recent field studies of Nepenthes talangensis at G. Talang by Nerz in 1986 and of Nepenthes bongso at G. Singgalang by Mr. and Mrs. DeWitte in 1993 (pers. com.) showed clearly that both are distinct species. This was also confirmed by the studies of available herbariummaterial of Nepenthes talangensis (The Bünnemeijer specimens cited above) and herbarium-material of Nepenthes bongso (Gunung Merapi, Korthals s. n. (L, Type); Gunung Singgalang, Beccari 268 (L)). See table 1 for a comparison of distinct characters of both species and other similar species.

\section{Nepenthes tenuis Nerz et Wistuba spec. nov.}

Planta tenuis. Folia mediocria sessilia lamina lanceolata, nervis longitudinalibus utrinque 3, basi attenuata $2 / 3$ caulis amplectente. Vagina 0 . Ascidia rosularum et inferiora ignota. Ascidia su periora parva, infundibuliformia, costis 2 elevatis; peristimio operculum versus accuminato in collum breve elevato, $6 \mathrm{~mm}$ lato, costis $1 / 8 \mathrm{~mm}$ distantibus; operculo anguste elliptico, facie inferiore plano. Inflorescentia ignota.

Holo-Typus: Meijer No 6949, Taram, sandstone region of river Tjampo on ridge, $1000 \mathrm{~m}$, 24.08.1957, H.L.B. No 958.86.006 (L).

Stems climbing, slender, the climbing part of the stem angular to rhomboid, 2-3 $\mathrm{mm}$ thick, the internodes $5-6,5 \mathrm{~cm}$ long. Rosettes and basal part of the stem unknown. Leaves of the climbing stems scattered, thin-coriaceous, sessile, lanceolate $5-6 \mathrm{~cm}$ long, $1-1,5 \mathrm{~cm}$ broad, acute, attenuate at the base, clasping the stem for $2 / 3$ without sheath. Nervation indistinct, the pennate nerves oblique, irregularly reticulate, the longitudinal ones about 3 on both sides originating from the basal 1/3 part of the midrib running parallel in the outer $1 / 2$ of the lamina. Tendrils $1,5 \mathrm{x}$ as long as the lamina, $0,5-1 \mathrm{~mm}$ thick, usually without curl. Indumentum sparse. Pitchers of the climbing stems gradually originating from the hanging end of the tendril incurved with a $10 \mathrm{~mm}$ wide curve, widely infundibuliform, contracted under the mouth $2,5-4,5 \mathrm{~cm}$ high, $1,5-2,5 \mathrm{~cm}$ 


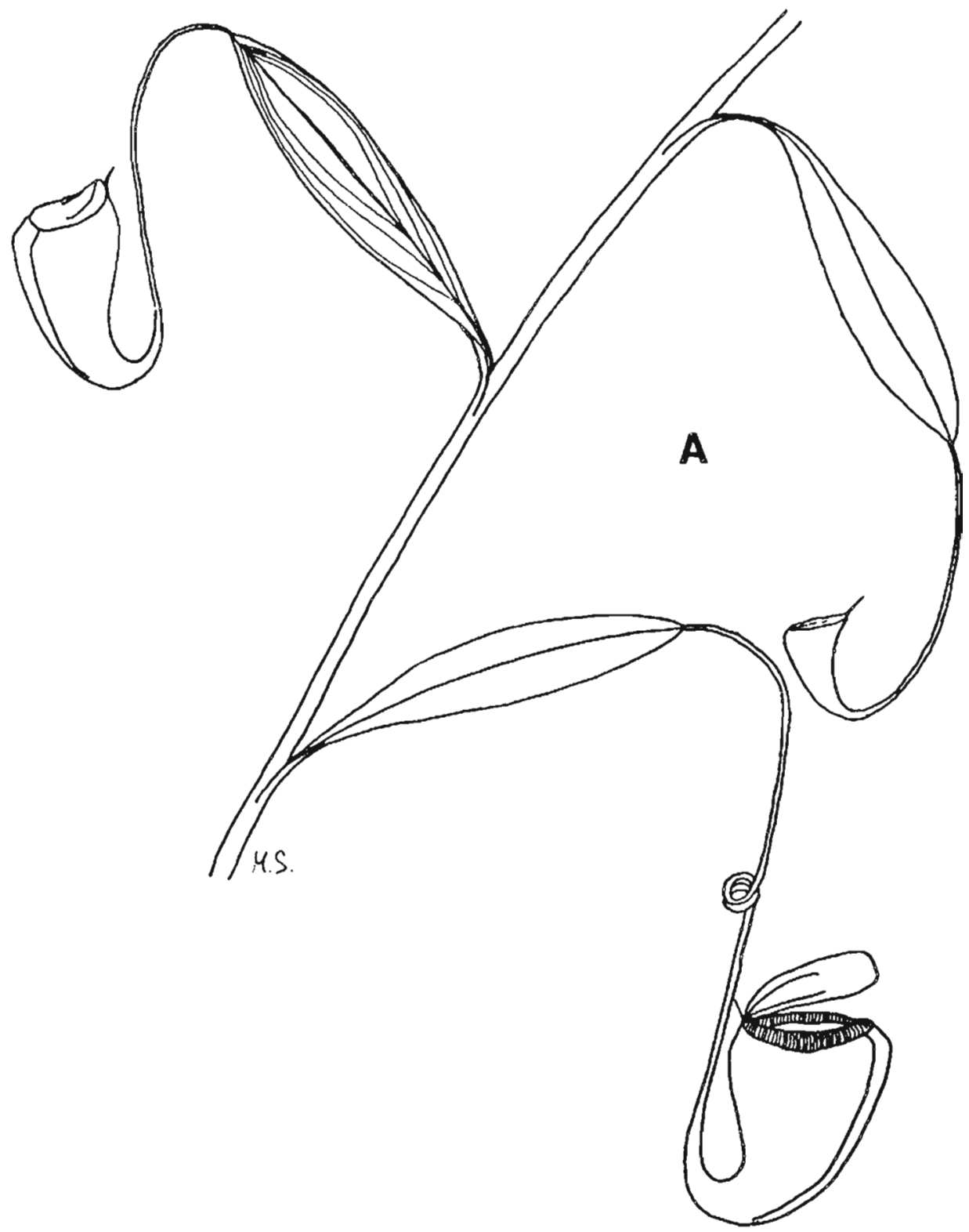

Fig. 2 Nepenthes tenuis (Nerz et Wistuba) A. Upper part of climbing stem (x3/4).

wide. 2 prominent ribs, $3-5 \mathrm{~mm}$ apart without fringes. Mouth ovate, almost horizontal, peristome flattened $6 \mathrm{~mm}$ wide, the ribs $1 / 8 \mathrm{~mm}$ apart. Inner surface of the pitcher with numerous small glands, about $600-800$ on $1 \mathrm{~cm}^{2}$. Lid narrow-elliptic $1,5-2,5 \mathrm{~cm}$ long, $0,5-0,8 \mathrm{~cm}$ wide with 2 prominent nerves, one on each side of the midrib. Glands evenly distributed on the underside of the lid. Spur unbranched, up to $1 \mathrm{~mm}$ long inserted close to the lid. Colour of herbarium specimens: dark brown Colour of living specimens: Pitchers with red-brown dots, peristome dark red-brownish. 
According to W. Meijer this species was found growing near Taram, West Sumatra, at a sandstone region of river Tjampo on a ridge at $1000 \mathrm{~m}$ altitude.

\section{Notes:}

This species is only known from the type collection by W. Meijer. It has not been recollected yet.

In table 1 we show some characteristics which clearly distinguish Nepenthes tenuis from similar species.

Tab. 1 。

Characteristics distinctive for $N$. talangensis, $N$. tenuis, $N$. bongso and $N$. dubia**.

\begin{tabular}{||l|l|l|l|l||}
\hline \hline & N. talangensis & N. tenuis & N. bongso & N. dubia \\
\hline $\begin{array}{l}\text { Shape of } \\
\text { upper pitchers }\end{array}$ & $\begin{array}{l}\text { tubulous to } \\
\text { narrow } \\
\text { infundibuliform } \\
\text { in the lower half, } \\
\text { ovate in the upper } \\
\text { half } \\
\text { infundibulate, } \\
\text { contracted below } \\
\text { the mouth } \\
\text { infundibulate }\end{array}$ & $\begin{array}{l}\text { nubulous in the } \\
\text { lower part, } \\
\text { infundibulate } \\
\text { above the middle }\end{array}$ & \\
\hline Lid & broad-ovate & $\begin{array}{l}\text { very narrow } \\
\text { elliptical }\end{array}$ & orbiculate & narrow cuneate \\
\hline $\begin{array}{l}\text { Length/width } \\
\text { patio of upper } \\
\text { pitchers }\end{array}$ & 2,3 & 1,75 & 3,3 & 1,9 \\
\hline
\end{tabular}

\section{Specimens examined:}

N.dubia: Bünnemeijer 938 G. Talakmau 1800 m, 29.05.1917,H.L.B. 320256164 (L); Bünnemeijer 938, G. Talakmau $1800 \mathrm{~m}, 29.05 .1917$ (BO).

N. bongso: Beccari 268 1878, G. Singgalang 1700 m, H.L.B. 908.155-85 (L); Junghuhn, Res. Tapiannoeli: G. Loebokraja, 1900 m, 11.1840 or 1841, H.L.B. 908.155-870 (L); Korthals, G. Merapi 2500 m, TYPE, H.L.B. 908.155-867 (L); Korthals legit, Sumatra (B ex L); Korthals legit, Sumatra (M ex L).

N. talangensis: Bünnemeijer 2552, G. Talang, 7.11.1918 H.L.B. 822.60 .920 (L); Bünnemeijer 5398, G. Talang $2200 \mathrm{~m}, 02.11 .1918$ (L); Bünnemeijer 6740, Bt. Gombak, $2330 \mathrm{~m}, 16.11 .1918$ (BO); Nerz 2501 (Holo-Type), short vine with flower and pitcher, G. Talang, $2200 \mathrm{~m}$, W-Sumatra, 06.09.1986 (L); Nerz 2502, leaf and pitcher of vine, alcohol-material, G. Talang, $2200 \mathrm{~m}, \mathrm{~W}$ Sumatra, 06.09.1986 (L); Nerz 2503, leaf and pitcher of rosette, G. Talang, $2200 \mathrm{~m}$, W-Sumatra, 06.09.1986 (L).

N. tenuis: Mejjer No 6949 (Holo Type), Taram, sandstone region of river Tjampo on ridge, 1000 $\mathrm{m}, 24.08 .1957$, H.L.B. No 958.86.006 (L).

\section{Nepenthes longifolia Nerz et Wistuba spec. nov.}

Folia mediocria, lamina oblonga vel lanceolata, nervis longitudionalibus utrinque $3-4$, basi in alas 2 decurrente; Ascidia rosularum mediocria, parte inferiore ventricosa os versus cylindrica, alis 2 fimbriatis; ascidia facie ventrali sub peristomio elevata quomodo peristomio inter alis distinctissime undulato, operculum versus acuminato et elevato, ad $6 \mathrm{~mm}$ lato, costis $0,2 \mathrm{~mm}$ distantibus, dentibus 0. Operculo orbiculari, facie inferiore plano. Ascidia superioria magna, e parte inferiore anguste infundibuliformi tubulosa, costis 2 prominentibus, ascidia facie ventrali sub peristomio elevata quomodo peristomio inter alis distinctissime undulato, operculum versus acu minato et elevato, ad $6 \mathrm{~mm}$ lato, costis $0,2 \mathrm{~mm}$ distantibus, dentibus 0 . Operculo orbiculari, facie inferiore plano. Inflorescentia racemus, pedicellis $1-1,2 \mathrm{~cm}$ longis, omnibus 2-floris. 
Holo-Typus: Nerz 2801, Tjampo-Mountains, near Taram, alt. 1000 m, W-Sumatra, 25.09.1992 (L).

Stems climbing, often up to $10 \mathrm{~m}$; part with adult leaves cylindrical 5-6 mm thick. Leaves of the rosette and short shoots lanceolate, sometimes lanceolate-spatulate, up to $50 \mathrm{~cm}$ long, obtuse, gradually attenuate into a short at most $5 \mathrm{~cm}$ long petiole, laterally flattened sheath clasping the stem for about 2/3. Pennate nerves numerous, indistinct, reticulate. The longitudinal ones 3-4 each side, running parallel in the outer half of the leaf. Tendrils shorter or up to as long as the lamina, without curl. Pitchers of the rosette very shortly incurved from the hanging tendrils, ventricose in the lower part, cylindrical in the upper part, up to $12 \mathrm{~cm}$ high, up to $4-5 \mathrm{~cm}$ broad in the lower part, up to $2-3 \mathrm{~cm}$ broad in the upper part, with two fringed wings over nearly the whole length. The wings about $3-4 \mathrm{~mm}$ broad, the fringe-segments 5-6 mm long, 1-3 mm apart. Mouth oblique, elevated and acuminate towards the lid. Peristome flattened, 6 $\mathrm{mm}$ wide, distinctly raised and usually slightly crumpled in front up to $5 \mathrm{~mm}$ on the sides, the ribs $0,2 \mathrm{~mm}$ apart. The interior margin entire. Inner surface of the pitcher glandular in the ventricose part with 500 overarched glands $/ \mathrm{cm}^{2}$. Lid orbicular, $2-3 \mathrm{~cm}$ in diameter, the interior surface without appendages, with large round to ovate glands towards the midrib, glandless towards the margin. Spur non-branched, up to $1 \mathrm{~cm}$ long. Leaves of the climbing stems lanceolate up to $30 \mathrm{~cm}$ long, $4-5 \mathrm{~cm}$ broad, ending in a distinct $6-7 \mathrm{~cm}$ long petiole, decurrent in two narrow wings, $1-2 \mathrm{~mm}$ wide, over almost the whole length of the internode. Pennate nerves numerous, indistinct, reticulate. The longitudinal ones 3-4, on each side, running parallel in the outer half of the leaf. Tendrils shorter or up to as long as the lamina, often with curl. Pitchers of the climbing stem gradually originating from the hanging end of the tendril, incurved with a curve up to $4 \mathrm{~cm}$ wide, narrowly infundibuliform in the lower half, tubulose in the upper half, 18-25 cm high, 2,5-3,5 cm wide with two prominent ribs over the whole length. Mouth oblique, elevated and acuminate towards the lid. Peristome flattened up to $6 \mathrm{~mm}$ wide, distinctly raised and crumpled in front with 3 prominent folds, up to $5 \mathrm{~mm}$ on the sides, the ribs $0,2 \mathrm{~mm}$ apart. The interior margin entire. Inner surface of the pitcher glandular in the infundibulate part with 500 overarched glands $/ \mathrm{cm}^{2}$. Lid orbicular, $2-3 \mathrm{~cm}$ in diameter, the interior surface without appendages, with large, round to orbicular glands towards the midrib, glandless towards the margin. Spur non-branched, up to $1 \mathrm{~cm}$ long. Male flower a raceme. Peduncle $15-20 \mathrm{~cm}$ long, about $3 \mathrm{~mm}$ thick at the base, $1 \mathrm{~mm}$ thick at the top, the axis $10-12 \mathrm{~cm}$ long, pedicels all of them two-flowered, wi thout bract, up to 1-1,2 cm long. Tepals narrow elliptical $4-5 \mathrm{~mm}$ long. Staminal column $5 \mathrm{~mm}$ long, the anthers included. Female inflorescence unknown. Indumentum sparse, with stellate hairs. Margin of the leaves densely covered with red hairs. Colour of herbarium specimen: leaves greenish brown, pitchers brown. Colour of living specimen: Leaves green, underside sometimes reddish, leaves of the rosette often with a red midrib. Lower pitchers brownish red, peristome usually green to reddish-green, innerside of the pitcher pale green, lid red. Pitcher of the climbing stem light green.

\section{Distribution and ecology:}

Growing on ridges of Gunung Tjampo near Payakumbuh, West Sumatra. The species was found growing in light submontaneous forest at $1000 \mathrm{~m}$ altitude. The plants were growing in several patches disjunct from each other. Other Nepenthaceae growing on Gunung Tjampo are Nepenthes alata, $N$. albomarginata and $N$. reinwardtiana. Hybrids with Nepenthes alata were observed. 


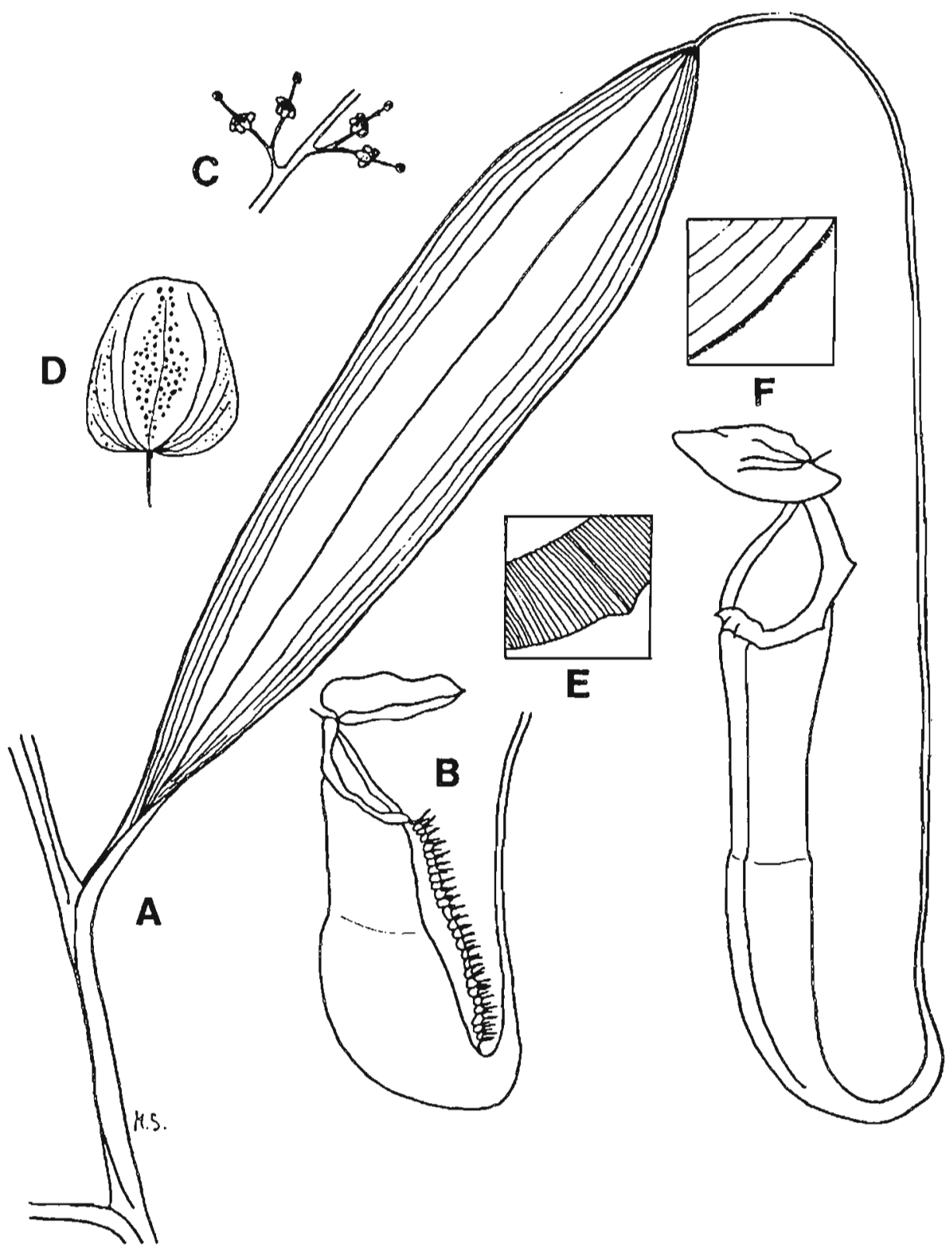

Fig. 3 Nepenthes longifolia (Nerz et Wistuba) A. leaf and pitcher of climbing stem $(x 3 / 10) ; B$. ground pitcher $(x 1 / 2)$; C. part of male inflorescense (x 2/3); D. lower side of lid (x 1/2); E. part of rim (x 2); F. part of leaf ( $x 3 / 4)$. 


\section{Notes:}

The species has been found by J. Nerz on Gunung Tjampo in September 1992. Specimens which might represent the same species were collected in 1956 by W. Meijer in the same area.

In table 2 we show some characteristics which clearly distinguish $N$. longifolia from similar species.

\section{Tab. 2。}

Characteristics of $N$. longifolia compared to similar species.

\begin{tabular}{||l|l|l|l||}
\hline $\begin{array}{l}\text { Shape of lower } \\
\text { pitcher }\end{array}$ & $\begin{array}{l}\text { ve longifolia } \\
\text { lower part, tubulous } \\
\text { in the upper part }\end{array}$ & $\begin{array}{l}\text { rounded at the base, } \\
\text { conical in the upper } \\
\text { part }\end{array}$ & $\begin{array}{l}\text { globose or broad } \\
\text { ventricose in the lower } \\
\text { part, tubulous in the } \\
\text { upper part }\end{array}$ \\
\hline $\begin{array}{l}\text { Shape of upper } \\
\text { pitcher }\end{array}$ & $\begin{array}{l}\text { narrow infundibulate } \\
\text { in the lower, tubulous } \\
\text { and glandless in the } \\
\text { upper part }\end{array}$ & $\begin{array}{l}\text { infundibulate, without } \\
\text { tubulous glandless } \\
\text { part }\end{array}$ & $\begin{array}{l}\text { infundibulate, without } \\
\text { tubulous glandless } \\
\text { part }\end{array}$ \\
\hline Flowers & always two-flowered & one-flowered & one- or two-flowered \\
\hline
\end{tabular}

* Recollections of $N$. treubiana at the type-locality (Wistuba) and of N. sumatrana (Nerz et Wistuba) showed clear morphological differences between these two species. Therefore we follow the nomenclature of Beck (1895), who elevated $N$. sumatrana to specific rank. It was originally described as $N$. boschiana var. sumatrana by Miquel (1858) and recombined as $N$. maxima var. sumatrana by Beccari (1886).

\section{Specimens examined:}

N. longifolia: Meijer No 6913, Taram, sandstone region of river Tjampo, 500-1000 m, forest against slope of river-valley, 24.08.1957, H.L.B. 958.85111 (L); Nerz 2801 (Holo-Type), TjampoMountains, nearTaram, alt. $1000 \mathrm{~m}$, W-Sumatra, 25.09.1992(L); Nerz 2802, Tjampo-Mountains, near Taram, alt. $1000 \mathrm{~m}$, W-Sumatra, 25.09.1992 (L); Nerz 2803, Tjampo-Mountains, near Taram, alt. 1000 m, W-Sumatra, 25.09.1992 (L); Nerz 2804, Tjampo-Mountains, near Taram, alt. 1000 m, W-Sumatra, 25.09.1992 (L); Nerz 2805, Tjampo-Mountains, near Taram, alt. $1000 \mathrm{~m}, \mathrm{~W}$ Sumatra, 25.09.1992 (L); Nerz 2806, Tjampo-Mountains, near Taram, alt. $1000 \mathrm{~m}$, W-Sumatra, 25.09.1992 (TUB); Nerz 2807, Tjampo-Mountains, near Taram, alt. $1000 \mathrm{~m}, \mathrm{~W}$-Sumatra, 25.09.1992 (TUB); Nerz 2808, Tjampo-Mountains, near Taram, alt. $1000 \mathrm{~m}$, W-Sumatra, 25.09.1992 (TUB).

N. sumatrana: Teysmann 535, Sibolga, coast, W.-Sumatra, 01-09.02.1856, type of N. boschiana var. sumatrana, H.L.B.928.350-86 (L); Teysmann 535, Sibolga to Tarutung, km 33, 02.1856 (BO).

\section{Nepenthes ovata Nerz et Wistuba spec. nov.}

Folia mediocria, sessilia. lamina angusta lanceolata, spathulata, apicem versus acuminata. Basi subcordata semiamplexicaulis. Vagina 0. Ascidia rosularum ovato conica, alis 2 fimbriatis, peristomio operculum versus elevato acuminato expanso $15-40 \mathrm{~mm}$ lato, costis $0,5-1,5 \mathrm{~mm}$ distantibus, dentibus $5 x$ longioribus quam latis. Operculo cordato-ovato, facie inferiore prope basin apendice lateraliter applanata obsito. Ascidia superiora magnitudine mediocria infundibuliformia, costis 2 prominentibus. Peristomio operculum versus acuminato in collum breve elongato, applanato, antice 2-5 mm, operculum versus 5-20 mmlato. Costis distantibus 0,5$1 \mathrm{~mm}$, dentibus $5 \mathrm{x}$ longioribus quam latis. Operculo cordato-ovato, facie inferiore prope basin apendice lateraliter applanata obsito. Inflorescentia racemus longus, pedicellis inferioribus 10 $15 \mathrm{~mm}$ longis, fere omnibus 2-floris. Indu mentum in partibus vegetativis parcissimum.

Holo-Typus: Nerz 1601, rosette with pitchers, G. Pangulubao, alt. 1800 m, N-Sumatra, 16.03 .89 (L).

Stems climbing, cylindrical, 4-6 mm thick, internodes $4-15 \mathrm{~cm}$. Leaves of the 
climbing stem scattered, sessile to broad-petiolate, lanceolate-spathulate, $5-12 \mathrm{~cm}$ long at the basis $1-1,5 \mathrm{~cm}$, at the middle part $2-3 \mathrm{~cm}$ wide. Tendril insertion of leaf-tip apical. Apex of the leaf abruptly narrowing into an acute tip, 0,8-1,2 cm long. Nerves longitudinal, 3 on each side, originating from the midrib near the base, in the outer $1 /$ 2 part of the lamina, meeting at the apex of the leaf. Leaves of the rosette sessile to broad petiolate, lanceolate-spathulate, $10-15 \mathrm{~cm}$ long, at the base $1 \mathrm{~cm}$ at the middle part $2-3 \mathrm{~cm}$ wide. Tendril insertion of leaf-tip apical, abruptly narrowing into an acute tip, 1-5 mm long. Rosette pitchers abruptly originating from the end of the tendril, pitcher ovate, infundibulate in the lower part, widest near the mouth, slightly narrowed towards the mouth. Pitchers usually $10-15 \mathrm{~cm}$, sometimes up to $25 \mathrm{~cm}$ in length, $5-6 \mathrm{~cm}$ wide, sometimes up to $9 \mathrm{~cm}$. With two prominent wings, $2-5 \mathrm{~mm}$ wide over the whole length. Fringes $3-10 \mathrm{~mm}$ long, $1-5 \mathrm{~mm}$ apart. Often the wings are reduced to ribs, bearing fringes only in the upper part of the pitcher. Mouth oblique, strongly incurved, acuminate and hanging over towards the lid, elongated into a triangular neck. Peristome expanded 3-7 mm broad in front, $15-25 \mathrm{~mm}$ or rarely up to $40 \mathrm{~mm}$ broad towards the lid. The ribs $0,5-1,5 \mathrm{~mm}$ apart at the outer side, teeth at the inner margin. Teeth of the inner margin in front of the mouth $1.3 \mathrm{~mm}$ long, towards the lid 1-7 mm long, teeth towards the lid broader. Inner surface almost wholly glandular, only a glandless triangle under the lid. Inner surface in the lower part with 400 overarched glands $/ \mathrm{cm}^{2}$ and 1300 overarched glands $/ \mathrm{cm}^{2}$ in the upper part. Lid at the midrib elevated to a lateraly flattened glandular claw-shaped crest up to $5 \mathrm{~mm}$ in length. Pitchers of younger plants sometimes without distinct crest. Spur up to $5 \mathrm{~mm}$ in length, branched. Pitcher with 14-18 longitudional nerves. Upper pitchers rather abruptly originating from the hanging end of the tendril. The curve $20-30 \mathrm{~mm}$ wide on the innerside, the ascending part usually tubulate-infundibuliform, $12-18 \mathrm{~cm}$ in length, in the tubular part 1,5-2 cm broad, 5-6 cm at the widest part, slightly narrowing towards the mouth. 2 non-prominent ribs over the whole length. Mouth oblique incurved, acuminate towards the lid. The ribs 0,5-1,0 mm apart at the outer site, with teeth at the inner margin. Pitcher with 14-18 longitudinal nerves. Inner surface almost wholly glandular, in the lower part with 400 overarched glands $/ \mathrm{cm}^{2}$, and 1300 overarched glands $/ \mathrm{cm}^{2}$ in the upper part. Lid: the midrib elevated to a laterally flattened, glandular, non branched appendage up to $5 \mathrm{~mm}$ in length with rather large glands especially near the midrib and at the appendage. Male inflorescense: A raceme, peduncles $4 \mathrm{~cm}$ in length, axis (without peduncle) $5 \mathrm{~cm}$ in length, slender, about $2 \mathrm{~mm}$ thick at the base. The pedicels all one-flowered with a filiform bract about as long as the pedicel. At the lower part, the pedicels are about $5 \mathrm{~mm}$ in length, at the upper part about $5 \mathrm{~mm}$ in length. Tepals ovate lanceolate about $3 \mathrm{~mm}$ long, $2 \mathrm{~mm}$ broad. Staminal column about $4 \mathrm{~mm}$ long the one-seriate anthers inclusive. Female inflorescence and seed unknown. Indumentum sparse with non branched hairs. Colours of the living specimens: Lower pitchers green, older pitchers suffused with red. Rim dark red, sometimes striped with green. Upper pitchers yellow, rim red with yellow stripes.

\section{Ecology:}

North-Sumatra, West-ridge of G. Pangulubao, $1800 \mathrm{~m}$, in wet mossy forest at open places, often growing in Sphagnum moss, the vines climbing into small trees. The plants were found growing in a rich mountain flora.

Other Nepenthaceae growing on the same mountain are Nepenthes spectabilis, Nepenthes rhombicaulis and Nepenthes tobaica. Nepenthes spectabilis is growing more scattered in montaneous forest at about the same altitude. Hybrids with Nepenthes spectabilis and Nepenthes rhombicaulis were observed.

\section{Notes:}

Nepenthes ovata from the Lake-Toba region shows characters clearly distinct from the related Nepenthes carunculata and is geographically isolated from all locations of Nepenthes carunculata known so far. 


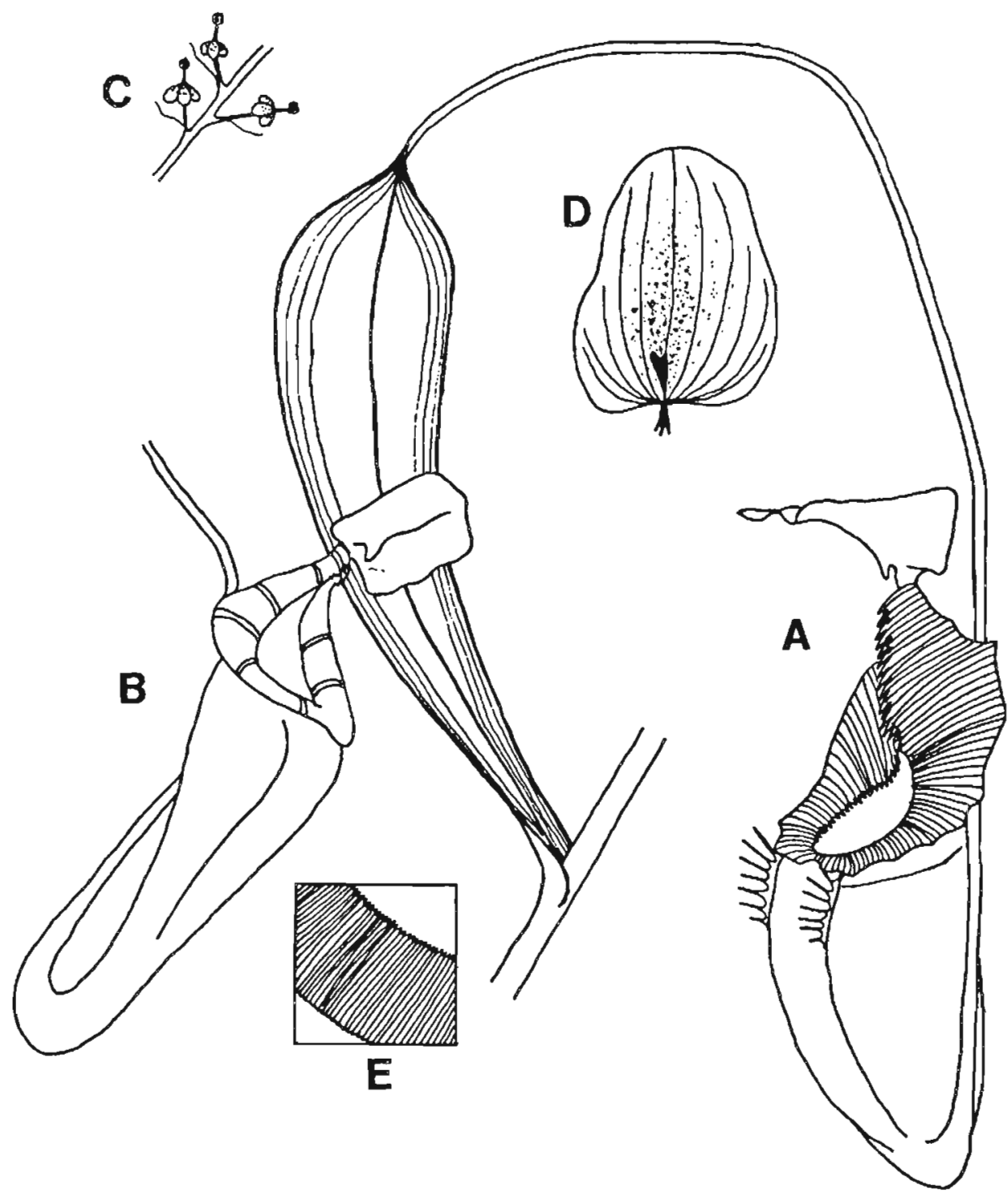

Fig. 4 Nepenthes ovata (Nerz et Wistuba) A. leaf and pitcher of lower part of the stem (x 1/2); B. pitcher of climbing stem (x 1/3); C. part of male inflorescense (x 3/4); D. lower side of lid (x 1/2); E. part of rim from upper pitcher $(x 1,5)$. 
Tab. 3。

Characteristics of Nepenthes ovata compared to related species**.

\begin{tabular}{|c|c|c|c|}
\hline & N. ovata & N. carunculata & N. singalana \\
\hline $\begin{array}{l}\text { Apical appendix } \\
\text { of the operculum }\end{array}$ & $=$ & $\begin{array}{l}\text { usually irregular } \\
\text { glandular appendix } \\
\text { near the apex of the } \\
\text { lid }\end{array}$ & 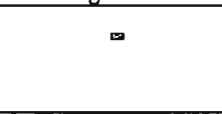 \\
\hline $\begin{array}{l}\text { Basal crest of the } \\
\text { operculum }\end{array}$ & $\begin{array}{l}\text { glandular, claw- } \\
\text { shaped crest near the } \\
\text { basis of the lid }\end{array}$ & $=$ & 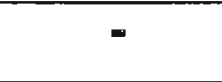 \\
\hline Leaf apex & $\begin{array}{l}\text { acuminate, apex } \\
\text { abruptly narrowing } \\
\text { into a distinct } \\
\text { triangle }\end{array}$ & $\begin{array}{l}\text { emarginate-peltate, } \\
\text { leaf apex rounded }\end{array}$ & rounded \\
\hline $\begin{array}{l}\text { Glands of } \\
\text { operculum }\end{array}$ & $\begin{array}{l}\text { glandular near the } \\
\text { midrib, densely } \\
\text { glandular near and } \\
\text { on the claw shaped } \\
\text { crest }\end{array}$ & $\begin{array}{l}\text { densely glandular } \\
\text { near the midrib of } \\
\text { the operculum, } \\
\text { obviously large } \\
\text { glands on the } \\
\text { appendage and in the } \\
\text { surrounding }\end{array}$ & $\begin{array}{l}\text { sparsely glandular } \\
\text { near the midrib, no } \\
\text { glands near the apex }\end{array}$ \\
\hline $\begin{array}{l}\text { Glandular zone } \\
\text { inside the pitcher }\end{array}$ & $\begin{array}{l}\text { ending always } \\
\text { immediately beneath } \\
\text { the peristome, } \\
\text { leaving only small } \\
\text { triangular glandless } \\
\text { zone }\end{array}$ & $\begin{array}{l}\text { cylindrical glandless } \\
\text { part of the pitcher } \\
\text { usually well } \\
\text { established }\end{array}$ & $\begin{array}{l}\text { cylindrical glandless } \\
\text { part of the pitcher } \\
\text { always well } \\
\text { established }\end{array}$ \\
\hline $\begin{array}{l}\text { Insertion of } \\
\text { operculum }\end{array}$ & $\begin{array}{l}\text { peristome incurved, } \\
\text { lid insertion above } \\
\text { the middle of the } \\
\text { pitcher-mouth }\end{array}$ & $\begin{array}{l}\text { bend of peristome } \\
\text { not prominent, lid } \\
\text { not inserted above } \\
\text { the pitcher mouth }\end{array}$ & $\begin{array}{l}\text { bend of peristome } \\
\text { not prominent, lid } \\
\text { not inserted above } \\
\text { the pitcher mouth }\end{array}$ \\
\hline Peristome teeth & $\begin{array}{l}\text { clearly visible at the } \\
\text { inner margin of the } \\
\text { mouth }\end{array}$ & $\begin{array}{l}\text { facing towards the } \\
\text { inner wall of the } \\
\text { pitcher and therefore } \\
\text { barely visibic }\end{array}$ & $\begin{array}{l}\text { clearly visible at the } \\
\text { inner margin of the } \\
\text { mouth }\end{array}$ \\
\hline
\end{tabular}

\section{Specimen examined:}

N. ovata: Nerz 1601 (Holo-Type), rosette with pitchers, G. Pangulubao, alt. 1800m, N-Sumatra, 16.03.89 (L); Nerz 1602, vine with pitchers and male flowers, G. Pangulubao, alt. $1800 \mathrm{~m}, \mathrm{~N}$ Sumatra, 16.03.89 (L); Nerz 1603, vine with male flowers, G. Pangulubao, alt. $1800 \mathrm{~m}, \mathrm{~N}$ Sumatra, 16.03.89 (L).

N. carunculata: Bünnemeijer 4027, G. Sago, $2000 \mathrm{~m}, 26.07 .1918$ (BO); Bünnemeijer 4230, G. Malintang, 1700 m, 01.08.1918 (BO); Bünnemeijer 5747, Bt. Gombak, 2330 m, 16.11.1918, H.B. No 92918135 (BO); Bü nnemeijer 9696, G. Kerintji, 1800 m, 16.04.1920 (BO); Meijer 4571, Mt. Sago, 1800 m, 15.12.1956, H.L.B. 957.274-792 (L); Meijer 6142, Mt. Sago, 1700-1800 m, 19.06.1958 (L).

N. singalana: Bünnemeijer 4028, G. Sago, $2000 \mathrm{~m}, 26.07 .1918$ (BO); Bünnemejjer 4113, G. Malintang, $2000 \mathrm{~m}, 29.07 .1918$ (BO); Bünnemeijer 4114,G.Malintang, $2200 \mathrm{~m}(\mathrm{BO})$; Bünnemejjer 4179, G. Malintang, $2200 \mathrm{~m}, 01.08 .1918$ (BO) Bünnemeijer 10270, G. Kerinci, 07.05.1920 (BO); Meijer 3590, Mt. Sago, nothern slope, open facies, mossy forest, Payakumbuh, 1800-1900 m, 29.06.1955 (L); Meijer 5841, Mt. Singgalang, surrou nding of crater lake, subalpine veg., 2800m, 26.05.1957 (L); Schiffner, iter indicium 1991, G. Merapi, 2500 m, 30.07 .1894 (WU); Schiffner, G. Singgalang, summit, $2750 \mathrm{~m}, 25.07 .1918$ (L); Schiffner, iter indicium 1990, G. Singgalang, summit $2750 \mathrm{~m}, 25.07 .1894$ (WU).

\section{Nepenthes carunculata var. robusta Nerz et Wistuba var. nov.}

Differt a typo characteribus sequentibus:

Planta robusta. Lamina lato-spathulata, 2,5 x longioribus quam lata, apice peltata, margo laminae distincte undulatum.

Holo-Typus: Nerz 2401, rosette with pitchers, G. Gadut, mossy forest, alt $1800 \mathrm{~m}$, W-Sumatra, 06.03.1989 (L).

This variety is characterized by its robust appearance. The rosette-leaves are up 

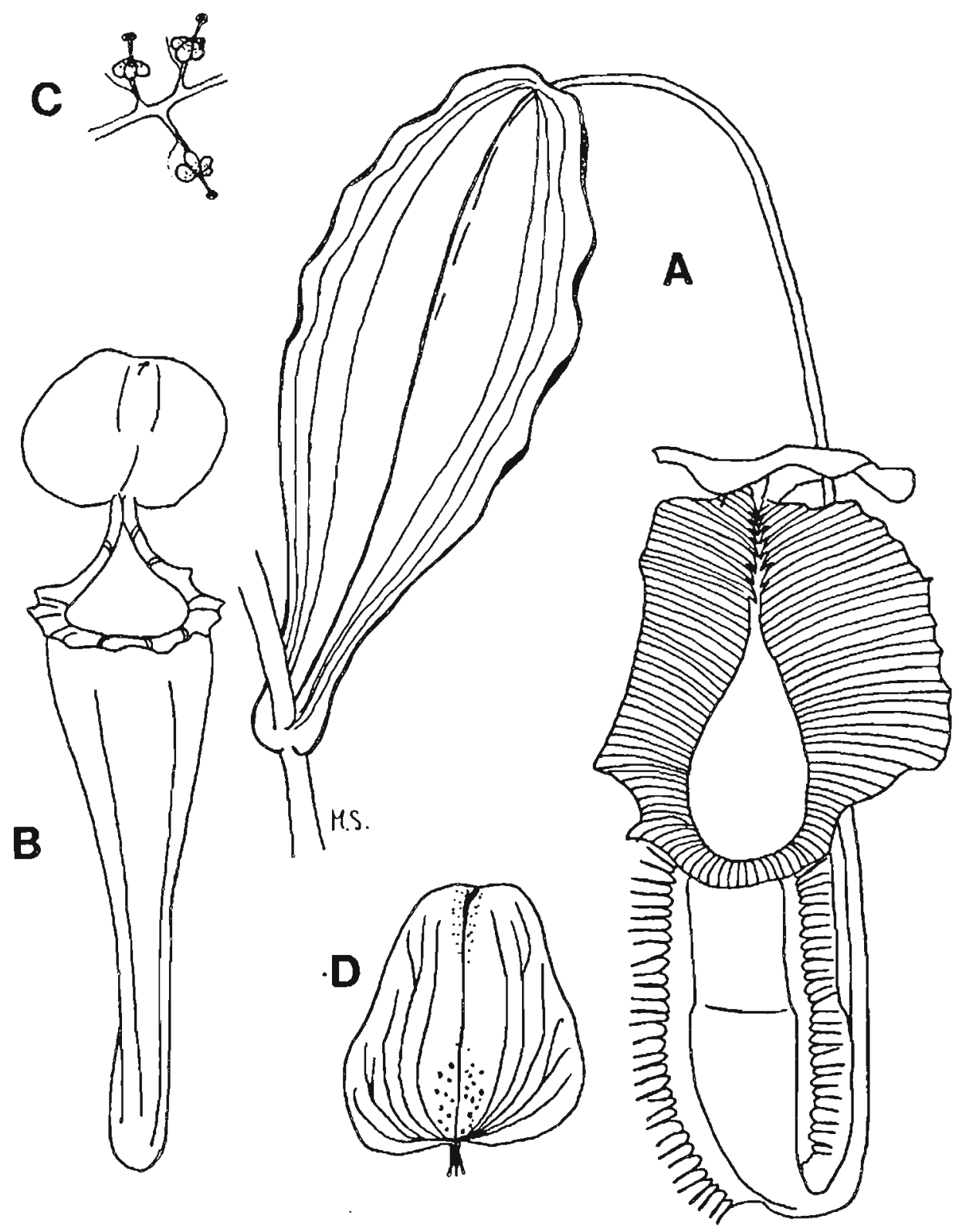

Fig. 5 Nepenthes carunculata var. robusta (Nerz et Wistuba) A. leaf and pitcher of lower part of the stem (x 2/5); B. pitcher of climbing stem (x 3/8); C. part of male inflorescense (x 3/4); D. lower side of lid (x 1/2). 
to 2,5 $\mathrm{x}$ as long as wide. The margins of the leaves are undulate and the tendril is usually inserted up to $1 \mathrm{~cm}$ below the apex of the lamina. The peristome of the rosettepitchers is extremely prominent, up to $4 \mathrm{~cm}$ wide.

\section{Ecology and distribution:}

Gunung Gadut, $1800 \mathrm{~m}$, open places in mossy forest. Nepent hes inermis and Nepenthes gymnamphora are growing together with this species in the same habitat.

Hybrids with Nepenthes inermis and Nepenthes gymnamphora were observed.

\section{Specimens examined:}

N. carunculata var. robusta: Nerz 2401 (Holo-Type), rosette with pitchers, G. Gadut, mossy forest, alt $1800 \mathrm{~m}$, W-Sumatra, 06.03 .1989 (L); Nerz 2402, vine with pitchers, G. Gadut, mossy forest, alt $1800 \mathrm{~m}$, W-Sumatra, 06.03.1989 (L).

Colour slides of living specimens growing in their natural habitat have been submitted to the photo-collection of the Rjjksherbarium in Leiden for Nepenthes carunculata, $N$. carunculata var. robusta, $N$. dubia, $N$. longifolia, $N$. ovata, $N$. singalana, $N$. talangensis and $N$. sumatrana.

**We do not agree with the opinions of Tamin and Hotta who made some suggestions for nomenclatural changes among Sumatran species of Nepenthes. They unite the taxa Nepenthes inermis, Nepenthes bongso, Nepenthes dubia and Nepenthes talangensis (e.g. Bünnemeijer 5398 from Gunung Talang) into one taxon, Nepenthes bongso (Tamin and Hotta, 1986, page 83). Further Tamin and Hotta unite Nepenthes carunculata, Nepenthes singalana, Nepenthes spathulata and others to one taxon, Nepenthes singalana (Tamin and Hotta, 1986, page 98). After having studied the representative type-specimens and specimens growing in the wild we feel that these nomenclatural changes are not justified. Besides the new taxon Nepenthes talangensis we therefore use the nomenclature of Danser (1928) in this publication which is generally accepted among botanists.

\section{Remark:}

We want to thank Don Schnell and Steve Baker who gave us the opportunity to publish the first validating descriptions which ever appeared in CPN. We feel that CPN is a very good organ for this matter, since it is well established among botanists and enthusiasts dealing with carnivorous plants.

\section{Acknowledgements:}

We want to thank Matthias and Oliver Schmidt who prepared the illustrations for this paper. We are grateful to the staff of the herbaria in Leiden (L) and Bogor (BO) for the opportunity to study their specimens of Nepenthaceae.

\section{Literature:}

Beccari, O., Malesia, III (1886-1890); Rivista delle specie del genere Nepenthes, p. 115 (1886).

Beck von Mannagetta, G. Ritter, Die Gattung Nepenthes. Wiener Mlustrierte Gartenzeitung (1895).

Danser, B. H., The Nepenthaceae of the Netherland Indies. Bulletin Jard. Bot. Buitenzorg, Série III. Vol. IX. Livr. 3-4 (1928).

Korthals, P. W., Over het geslacht Nepenthes. In: C. J. Temminck, Verhandelingen over de natuurlijke geschiedenis der Nederlandsche overzeesche bezittingen; Kruidkunde (1839-1842), p. 1-44, t. 1-4, 13-15, 20-22 (1839). 
(1908).

Schlauer, J. and J. Nerz, Notes on Nepenthes (Nepenthaceae) I: Contributions to the Flora of Sumatra. Blumea 39, p. 139-142 (1994), in press.

Tamin, R. and M. Hotta, The genus Nepenthes of the Sumatra island. In: M. Hotta (ed.), Diversity and dynamics of plant life in Sumatra, p. 75-109 (1986).

\section{News And Views}

Through August 1995, a small carnivorous plant display will be housed at the University of Wisconsin - Whitewater natural history museum, Upham Hall, third floor. The display features representatives of the following genera: Sarracenia, Drosera, Dionaea, Pinguicula, Utricularia and Nepenthes. If in the Whitewater area, please stop by and visit during the building open hours of 7:30 am to 6:00 pm week days.

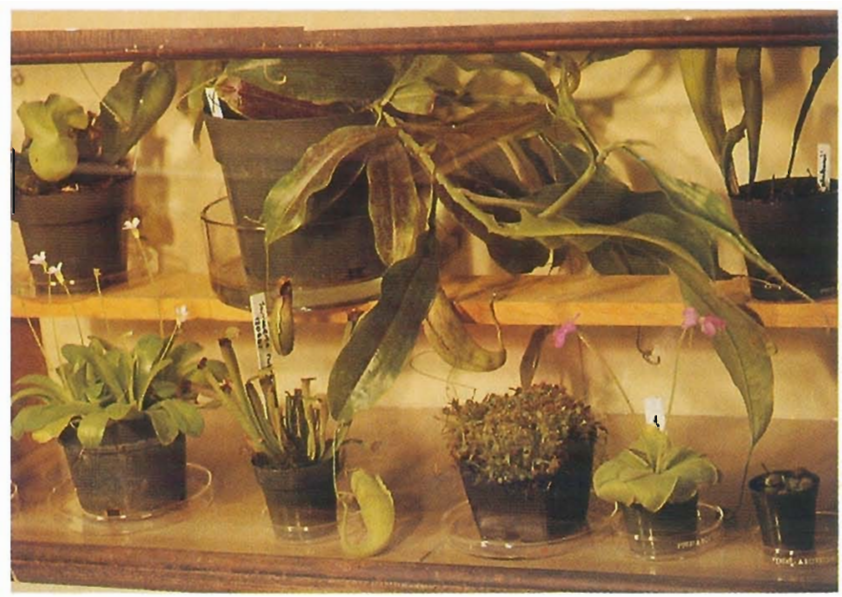

\section{CPN Binders}

Color-Pepper Green with White ink for art and text (CPN Mast Head) Binder Desc and Size- 1.5 inches capacity Binder 12 wire magazine medal for a 9 inches tall and 6 inches wide sheet size.

They use metal rods which are locked down through the inner division (central fold) of the mag. As I stated before they can hold 12 issues of your choice and can be removed at any time. The cost per binder will be $\$ 9.75$ per Binder (holds 12 CPNs) For Quantities of 25 or more, $20 \%$ Discount. Foreign orders: Add 20\%,Via Surface mail.

Please include $\$ 2.00$ shipping and Handling Make Check out to Steve Baker Send to: Steve Baker, Rt 1, Box 540-19AB, Conover, NC 28613, USA (Please allow four weeks for delivery, telephone orders not accepted)

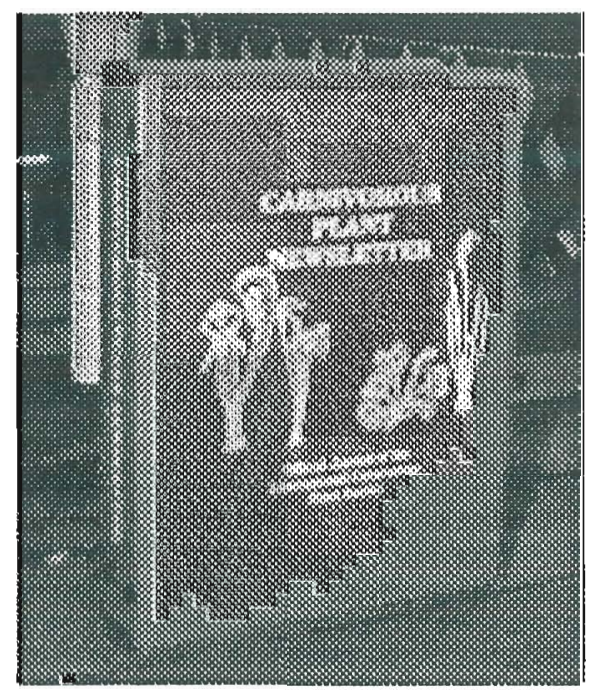

